\title{
Pharmacopoeia Analysis of Citrus aurantium L. Ssp. Amara engl. and it's fixed oil content
}

\author{
Ceylan Aka1, Ufuk Koca Çalişkan"1*, Fatma Baykara', Nazim Şekeroğlu² \\ ${ }^{1}$ Gazi University, Pharmacy Faculty, Department of Pharmacognosy, Etiler 06330, Ankara-TURKEY. \\ ${ }^{2}$ Kilis 7 Aralık University, Vocational School, Medicinal and Aromatic Programme, 79000 Kilis-TURKEY.
}

\begin{abstract}
Objective: Our aim was to take attention to Citrus aurantium L. ssp. amara Engl. (Rutaceae), which grows widely along the Mediterranean in Turkey where it has very limited medicinal usage. The bitter orange fruits/peels were analysed to find out if they are suitable to the standards in European Pharmacopoeia 7.0. The peel and fixed oil were investigated to Figure out the oil quality to apply in medicinal and cosmeceutical preparations. Material/Methods: C. aurantium were collected from different regions of Turkey, various fruit parts and their extracts were evaluated according to the Pharmacopoeia. The essential and fixed oils were obtained from their fruits and seeds, respectively. Seeds were crushed and fixed oil was obtained by cold squeezing. Essential oil yield, index analysis of fixed oil and drog analysis were conducted in compliance with the procedures. Results and Discussion: Evaluation of the peel was found appropriate to the Pharmacopoeia. Aydin, Iskenderun and Mersin regions have been suitable to cultivate valuable medicinally used product. Although $C$. aurantium has commercial and medicinal value around the world, it has not significant utilization in Turkey. Therefore this study could help recognizing its health benefits. Absolutely, phytochemical content should be taken into account before medicinal using.
\end{abstract}

Key words: Bitter orange, Citrus Aurantium, Pharmacopoeia analysis.

\section{INTRODUCTION}

Citrus aurantium L. ssp. amara Engl. known as bitter orange, Seville orange, sour orange (synonym. C. aurantium L. subsp. aurantium) belongs to Rutaceae family. It grows naturally in Northern India (Indian, Khasia Hills in Assam, and Central Provinces), Southeast Asia along with Mediterranean, temperate regions of America. ${ }^{1}$ It has very limited medical usage, mostly used to make drinks and liquor in all over the world, although the peel is used to make jam, no commercial value in Turkey whatsoever. ${ }^{2}$ The European Pharmacopoeia has description about C. aurantium flower, fruit epicarp-mesocarp and fruit tincture. ${ }^{3}$ The plant's fruit is $2.5-4.5$ in width and $4-8 \mathrm{~cm}$ in length. Its surface is reddish-yellow or brown, the other surface grayish red-yellow. It has an aromatic odor and bitter tasting. The fragrance of the fruit is mostly due to the volatile oils. The whole fruit contains flavonoids, terpens, carotenoids and coumarins apart from the main constituent volatile oils. ${ }^{4,5} \quad p$-Synephrine from biogenic amins is important in terms of toxicity/safety. ${ }^{6}$ Aim of this study, is to take attention to bitter orange in Turkey. The peel, and were analyzed for its suitability to the European Pharmacopoeia. The fixed oil from the seeds also was analyzed in order to figure out the oil quality to apply in medicinal and cosmeceutical usage.

\section{MATERIAL AND METHODS}

\section{Plant materials}

Fruits of bitter orange were collected from Adana, Antalya, Izmir and Mersin districts in Turkey. The peels of the fruits were dried in the shade.
DOI: $10.5530 /$ ijper.51.3s.67 Correspondence: Ufuk Koca Çalişkan, Gazi University, Pharmacy Faculty, Department of Pharmacognosy, Etiler 06330, Ankara-TURKEY Fax: +90 (312) 2235018 E-Mail: ukoca@gazi.edu.tr 
Pharmacopoeia analysis of the fruit epicarps and mesocarps

Experiments were conducted according to European Pharmacopoeia 7.0. ${ }^{3}$

\section{Determination of total ash of the peel}

Weighed and powdered materials were placed in a tared crucibles. Then, they have been placed in a muffle furnace at $600 \pm 25^{\circ} \mathrm{C}$ (about 2.5 hours) and they were burned. All the ash content was calculated as grams. ${ }^{3}$

\section{Determination of water content of the peel}

The amount of water was calculated as described in the pharmacopoeia. ${ }^{3}$

\section{Determination of extractable matter}

Each powdered plant material $(2 \mathrm{~g})$ was extracted with water:ethanol $(3 \mathrm{~mL}: 7 \mathrm{~mL})$. After filtration, the filtrate was evaporated to dryness in a water bath and dried in an oven at $100-105^{\circ} \mathrm{C}$ for 3 hours. ${ }^{3}$

\section{Volatile oil assay}

The amount of essential oils was calculated through the apparatus specified in pharmacopoeia for each sample. ${ }^{3}$

\section{Microscopic analysis of the fruit}

Powdered light brown materials were examined under microscope using chloral hydrate R. ${ }^{3}$

\section{Obtaining the fixed oil from the seed}

The fixed oil was obtained by cold squeezing (patent number: 2014/12733-2014-GE-46339). This oil is reddish-yellow color. Fatty acids in the fixed oil were analyzed with Gas chromatography (GC) by using flame ionization detector. ${ }^{7}$ For determination of the tocopherols, high-performance liquid chromatography-fluorescence detection (HPLC-FLD) was utilized. ${ }^{8}$

\section{Pharmacopoeia analysis of the fatty oils Acid value}

$1 \mathrm{~mL}$ of the substance to be examined was dissolved in $5 \mathrm{~mL}$ mixture of equal volumes of ethanol and ether. Phenolphthalein solution has been used as an indicator.
The mixture was titrated with $0.1 \mathrm{~N}$ alcoholic potassium hydroxide $(\mathrm{KOH})$ until the pink color persists for at least 15 s. $^{3}$

\section{Saponification value}

$2 \mathrm{~mL}$ of substance to be examined was placed in a reflux condenser. $25 \mathrm{~mL}$ of $0.5 \mathrm{~N}$ alcoholic potassium hydroxide was added. It was heated under reflux. It was titrated immediately with $0.5 \mathrm{~N}$ hydrochloric acid in the presence of phenolphthalein. A blank test was carried out under the same conditions. ${ }^{3}$

\section{Ester value}

It is calculated from the saponification value and acid value. $^{3}$

Ester value $=$ Saponification value - acid value

\section{lodine value}

The oil was dissolved in carbon tetrachloride and potassium iodide solution. Covered flask was kept in the dark for $30 \mathrm{~min}$. Potassium iodide and dissolved starch solution were added to the flask, then titrated with $0.1 \mathrm{~N}$ sodium thiosulfate until the yellow color discharged. A blank test was carried out under the same conditions. ${ }^{3}$

\section{Peroxide value}

The oil was dissolved in glacial acetic acid: chloroform $(18: 12 \mathrm{~mL})$ mixture and, $0.5 \mathrm{~mL}$ of saturated potassium iodide was added. Then $30 \mathrm{~mL}$ of water was added, the mix was titrated with $0.01 \mathrm{~N}$ sodium thiosulfate. Starch solution is added as indicator. And a blank test is carried out under the same conditions. ${ }^{3}$

\section{RESULTS}

Pharmacopoeia analysis on epicarp and mesocarp

Quantity of total ash, volatile oil, water and extractable matter were given Table1.

\section{Microscopic analysis}

Microscopic elements of fruit were given Figure 1.
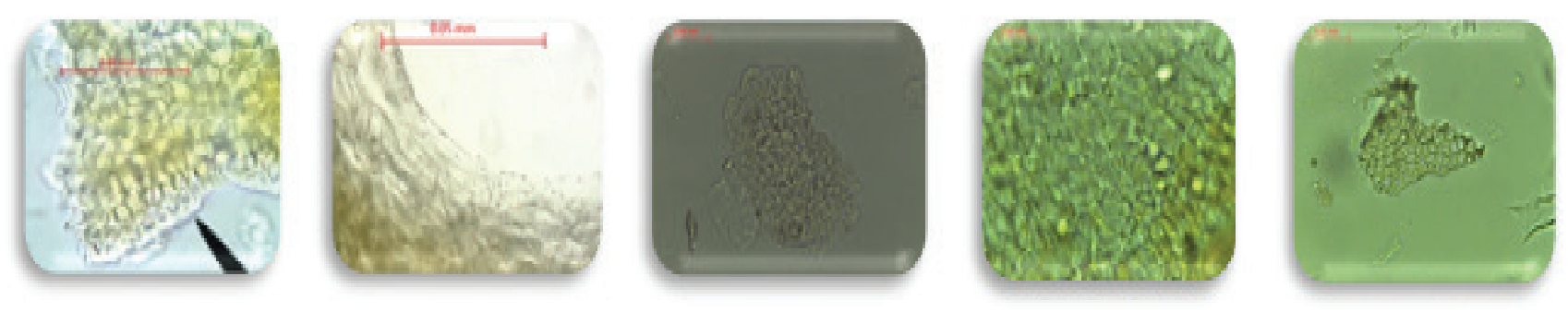

Figure 1: Microscopic examination of samples. a) Epicarp with thick cuticule, collenchymatous hypodermis,b) Fragments of lysigenous oil glands c) Epicarp with anomocytic stoma-in surface view, d) Fragment of mesocarp containing crystal of calcium oxalate), Mesocarp. 


\section{Table 1: Results of the pharmacopoeia analysis of the C. aurantium fruit peel samples}

\begin{tabular}{|c|c|c|c|c|}
\hline Collection site & $\begin{array}{c}\text { Total ash } \\
\mathbf{( g / g})\end{array}$ & $\begin{array}{c}\text { Volatile oil } \\
(\mathbf{m L} / \mathbf{g})\end{array}$ & $\begin{array}{c}\text { Extractable matter } \\
\mathbf{( m g})\end{array}$ & $\begin{array}{c}\text { Water content } \\
(\mathbf{m L} / \mathbf{g})\end{array}$ \\
\hline ADANA & $3,14 \pm 0,07$ & $0,45 \pm 0,24$ & $165,43 \pm 19,83$ & $8,13 \pm 0,53$ \\
\hline ADANA- Gülen & $3,63 \pm 0,11$ & $0,58 \pm 0,47$ & $118,13 \pm 36,44$ & $5,96 \pm 0,76$ \\
\hline ANTALYA & $4,41 \pm 0,15$ & $0,26 \pm 0,14$ & $157,07 \pm 22,03$ & $7,11 \pm 0,16$ \\
\hline AYDIN & $3,92 \pm 0,08$ & $0,75 \pm 0,50$ & $155,00 \pm 15,63$ & $9,99 \pm 0,01$ \\
\hline HATAY- Dörtyol & $3,20 \pm 0,29$ & $0,91 \pm 0,20$ & $205,27 \pm 49,65$ & $4,62 \pm 3,01$ \\
\hline ISKENDERUN & $3,32 \pm 0,20$ & $1,04 \pm 0,32$ & $265,40 \pm 34,87$ & $7,49 \pm 0,72$ \\
\hline IZMIR & $1,96 \pm 0,16$ & $1,09 \pm 0,10$ & $119,63 \pm 47,61$ & $9,22 \pm 1,05$ \\
\hline MERSiN & $2,96 \pm 0,22$ & $0,95 \pm 0,04$ & $233,93 \pm 23,90$ & $6,99 \pm 0,69$ \\
\hline MERSIN- Alata & $5,13 \pm 0,07$ & $0,64 \pm 0,21$ & $184,93 \pm 32,09$ & $6,00 \pm 0,71$ \\
\hline MERSIN- PInar & $4,95 \pm 0,33$ & $0,98 \pm 0,08$ & $255,00 \pm 17,42$ & $5,48 \pm 2,14$ \\
\hline MERSIN- Silifke & $3,81 \pm 0,32$ & $0,91 \pm 0,17$ & $288,33 \pm 16,08$ & $8,24 \pm 1,05$ \\
\hline OSMANIYE & $3,35 \pm 0,24$ & $0,91 \pm 0,17$ & $175,67 \pm 17,24$ & $6,61 \pm 2,30$ \\
\hline
\end{tabular}

\section{Table 2: Seed oil index values}

\begin{tabular}{|c|c|}
\hline Parameters & Seed oil index \\
\hline Acid value & $4,05 \pm 0,22 \mathrm{KOH} \mathrm{mg} / 1 \mathrm{~g}$ \\
\hline Saponification value & $251,28 \pm 2,80 \mathrm{KOH} \mathrm{mg} / 1 \mathrm{~g}$ \\
\hline Ester value & $247,24 \pm 2,58 \mathrm{KOH} \mathrm{mg} / 1 \mathrm{~g}$ \\
\hline lodine value & $31,28 \pm 1,73 \mathrm{~g} / \mathrm{g}$ \\
\hline Peroxide value & $0,50 \pm 0,03$ milliequivalents $/ \mathrm{kg}$ \\
\hline
\end{tabular}

\section{Table 3: Quantity of fatty acids}

\begin{tabular}{|c|c|}
\hline Fatty acid & Quantity (\%) \\
\hline Linoleic acid & 33,02 \\
\hline Oleic acid & 26,50 \\
\hline Palmitic acid & 23,86 \\
\hline Linolenic acid & 7,92 \\
\hline Stearic acid & 7,11 \\
\hline
\end{tabular}

\begin{tabular}{|c|c|}
\hline \multicolumn{2}{|c|}{ Table 4: Quantity of tocopherols } \\
\hline Tocopherols & Quantity $(\mathbf{m g} / \mathbf{k g})$ \\
\hline Alpha tocopherol & $87 \pm 4,736$ \\
\hline Gamma tocopherol & $30 \pm 1,32$ \\
\hline
\end{tabular}

\section{Pharmacopoeia analysis on fatty oils}

Seed oil index was given Table 2.

\section{Quantity of fatty acids and tocopherols}

Quantity of fatty acids and tocopherols were given Table 3 and Table 4.

\section{DISCUSSION}

According to the results of peels, Aydin, Iskenderun and Mersin districts were suitable to cultivate desirable medicinal product. Peels of fruits gathered from these regions were appropriate to pharmacopoeia standard. Saponification, acid and ester index are very important to detect purity/quality control of drogs that carry volatile and fixed oils. The saponification index is a characteristic for each oil and is a parameter in determining the adulteration. Also, it gives information about fatty acids. The saponification index value of the bitter orange fixed oil was higher compared with olive oil. Acid value was directly proportional to saponification value. Another important criterion is iodine value which is degree of unsaturation. The presence of unsaturated fatty acid component in oil is essential for cardiovascular health. Oleic, linoleic and linolenic acids are unsaturated acids. Whereas oleic acid is lower, palmitic, linoleic and linolenic acid are more in bitter orange oil than olive oil. Iodine value is lower than compared olive oil's. ${ }^{9}$ Also, peroxide value of bitter orange oil was quite low. We can say that oxidation did not occur in bitter orange oil and this oil did not deteriorate. Different isomeric forms of tocopherols conduce fundamentally to the health improvement. ${ }^{10-12}$ Tocopherols which are a precursor of vitamin E, especially gamma tocopherol, relatively large quantity in bitter orange oil. When bitter orange oil compared with olive oil that is important nutritional and medicinal oil in terms of fat's index values, we couldn't reach the result of using bitter orange oil instead of olive oil. Bitter orange oil is promising the future in terms of its fatty acids even if bitter orange oil is not an alternative to 
olive oil. Besides, phytochemical content must be taken into account before using.

\section{CONCLUSION}

Herbal medicine sector should focus on bitter orange to produce medicinal and dietary products because of its rich phytochemical content. Although this plant is medicinally used widely around the world, it has not widespread utilizing in Turkey. Through this study, its benefits will be recognized and will be allowed to be consumed by Turkish people.

\section{ACKNOWLEDGEMENT}

The authors would like to express geniune thanks to the financial support provided by the Gazi University Scientific Research Projects Unit, with the project number of 02/2012-44. The authors would like to express their thanks to Mehmet Şimşek for providing fixed oil and obtaining GC and HPLC results in better quality.

\section{CONFLICT OF INTEREST}

The authors have declared that no conflict of interest exists.

\section{ABBREVIATION USED}

G: gram; GC: Gas chromatography; HPLC: Highperformance liquid chromatography; HPLC-FLD: High-performance liquid chromatography-fluorescence detection; kg: kilogram; $\mathrm{KOH}$ : potassium hydroxide; Mg: milligram; Min : minute; mL: milliliter; $\mathrm{N}$ : normality

\section{REFERENCES}

1. Quintero A, de Gonzalez CN, Sanchez F, Usubillaga A, Rojas L, Szoke E, et al. Constituents and biological activity of Citrus aurantium amara $L$. essential oil. Acta Horticult. 2003;597:115-7.

2. Colombo E, Ghizzoni C, Cagni D. Citrus oils in food and beverages: uses and analysis. In: Dugo J, DiGiacomo A (eds.). Citrus: The genus Citrus. London \& New York: Taylor \& Francis. 2002.

3. European Pharmacopoeia Commission. European Pharmacopoeia 7.0. European Directorate for the Quality of Medicines (EDQM) 2011;4101-4103.

4. Chouchi D, Barth D, Reverchon E, Porta DE. Bigarade peel oil fractionation by supercritical carbon dioxide desorption. J Agric Food Chem. 1996;44(4):1100-4.

5. Boelens $\mathrm{MH}$, Jimenez R. The chemical composition of the peel oils from unripe and ripe fruits of bitter orange, citrus. Flav Fragr J. 1989;4(3):139-42.

6. Chen G, Zhang L, Zhao J, Ye J. Determination of hesperidin and synephrine in Pericarpium Citri Reticulatae by capillary electrophoresis with electrochemical detection. Anal Bio anal Chem. 2002;373(3):169-73.

7. Haiyan Z, Bedgood DR, Bishop AG, Prenzler PD, Robards K. Endogenous biophenol, fatty acid and volatile profiles of selected oils. Food Chem. 2007;100(4):1544-51.

8. Górnaś P, Siger A, Polewski K, Pugajeva I, Waśkiewicz A. Factors affecting tocopherol contents in coffee brews: NP-HPLC/FLD, RP-UPLC-ESI/MSn and spectroscopic study. Eur Food Res Technol. 2014;238(2):259-64.

9. FAO / WHO, 1981. Codex Alimentarius. International Food Standards. Standard for olive oils and olive-pomace oils. CODEX STAN 33-1981. Adopted in 1981. Revision: 1989, 2003, 2015. Amendment. 2009, 2013.

10. Constantin BMC, Raducu C, Miresan V, Negrea O. Tocopherol content in vegetable oils using a rapid HPLC fluorescence detection method. Not Bot Horti Agrobot Cluj Napoca. 2013;41(1):93.

11. Sultan MT, Butt MS, Anjum FM, Jamil A, Akhtar S, Nasir M. Nutritional profile of indigenous cultivar of black cumin seeds and antioxidant potential of its fixed and essential oil. Pak J Bot. 2009;41(3):1321-30.

12. Azam, MM, Waris A, Nahar NM. Prospects and potential of fatty acid methyl esters of some non-traditional seed oils for use as biodiesel in India. Biomass Bioenergy. 2005;29(4):293-302.

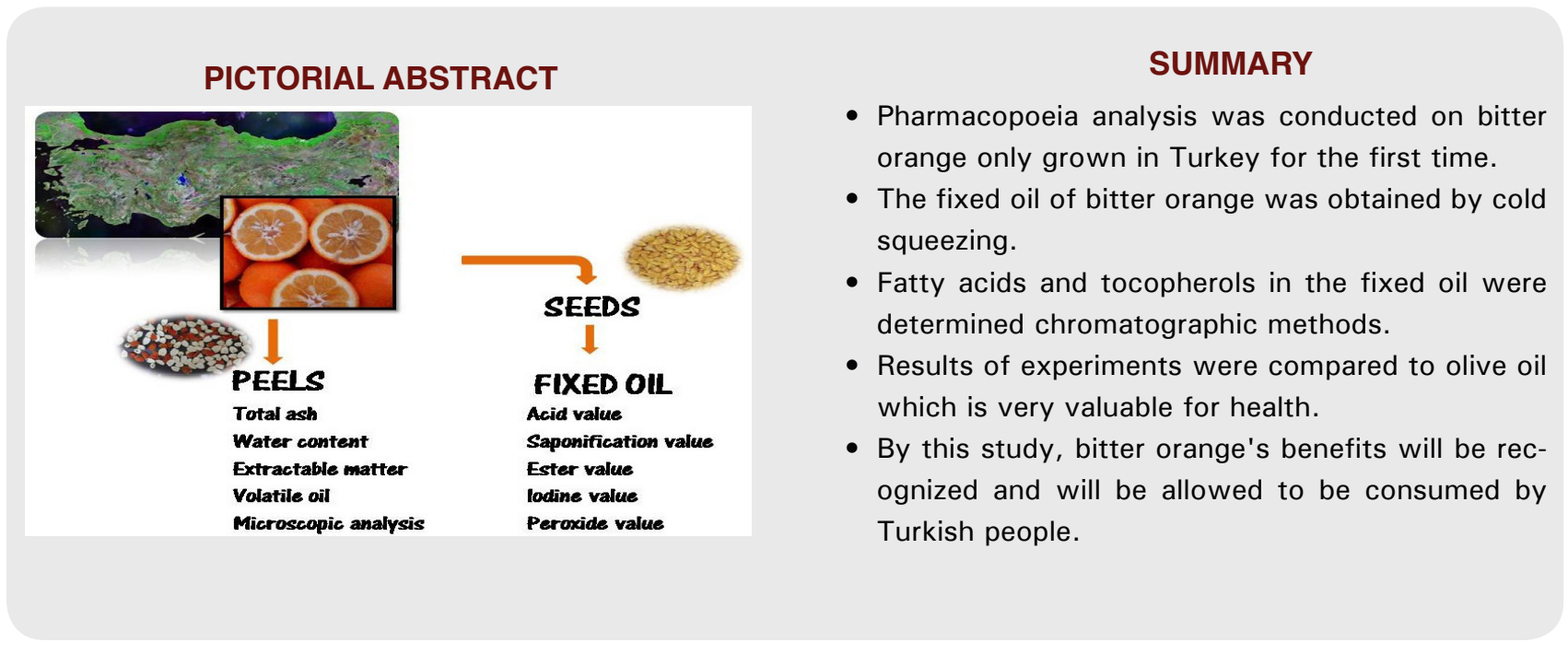




\section{ABOUT AUTHORS}

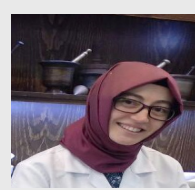

Ceylan Aka: Research Assistant, PhD Student: 2013- Gazi University, Faculty of Pharmacy, Department of Pharmacognosy, Etiler 06330, Ankara-TURKEY.

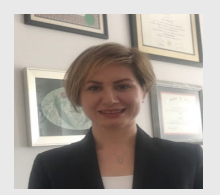

Ufuk Koca-Calișkan: Associate Professor, 2011- Gazi University, Faculty of Pharmacy, Department of Pharmacognosy, Etiler 06330, Ankara-TURKEY, PhD: 1999-2004, University of Florida, Master: 1996-1998, Washington State University

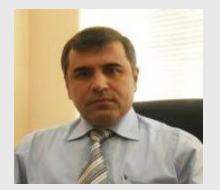

Nazim Șekeroğlu: Professor, Professor: 2013- Kilis 7 Aralik University, Vocational School, Medicinal and Aromatic Programme, 79000 Kilis-TURKEY, Associate Professor: 2008-2013 Kilis 7 Aralik University, Vocational School, Medicinal and Aromatic Programme, 79000 Kilis-TURKEY.

Fatma Baykara: Pharmacist, Master Student: 2014- Gazi University, Faculty of Pharmacy, Department of Pharmacognosy, Etiler 06330, Ankara-TURKEY.

Cite this article: Aka C, Çaliskan UK, Baykara F, Sekeroglu N. Pharmacopoeia Analysis of Citrus aurantium I. Ssp. Amara engl. And it's fixed oil content. Indian J of Pharmaceutical Education and Research. 2017;51(3)Suppl:S458-62. 